\title{
DIE NEO-MARXISTIESE POLITIEKE TEOLOGIE
}

Dr. J. M. Vorster.

\section{Inleiding}

Die uitdrukking: Neo-Marxistiese Politieke Teologie is 'n versamelterm van al die kontemporêre teologiese strominge wat met die moderne samelewingsvraagstukke as hermeneutiese uitgangspunt en die Neo-Marxisme as polities-ideologiese voedingsbron die Bybel en die Christelike geloof interpreteer as 'n politieke kritiek en 'n sosiaalmaatskaplike verlossingsleer. Die belangrikste oorsese eksponente van hierdie rigting is Cox, Moltmann, Metz, Sölle, Shaull, Fierro en Gutierrez. In Suider-Afrika word hierdie Teologie uitgebou en in die Suid-Afrikaanse konteks toegepas deur teoloë soos Banana, Boesak en Tutu.

Hierdie teologiese rigting kan met reg beskou word as die belangrikste ontwikkeling in die hedendaagse teologiese denke. Dit is 'n internasionale stroming wat geen kerklike of konfessionele grense ontsien nie. Daar is verteenwoordigers uit die Rooms-Katolieke kerk (Fierro) en Protestantse kringe (Metz, Moltmann, Sölle en Shaull). Dit is lewend in die ontwikkelde wêreld (Cox en Lochman) en in die Derde Wêreld (Gutierrez, Castro, Banana, Tutu en Boesak).

In Suid-Afrika het die rigting in die afgelope dekade ook baie aktueel geword en bepaal dit tans in 'n groot mate die getuienis van kerke en die optrede van gelowiges alhier. Die aktualiteit kan enersyds toegeskryf word aan die land se politieke problematiek, wat meegebring het dat maatskaplike verandering tans hier baie tersake is. Die politieke problematiek bied lewensruimte aan 'n teologie wat maatskappy-krities gerig is en transformerend op die samelewing wil inwerk. Andersyds moet die aktualiteit van die stroming in SuidAfrika toegeskryf word aan die doelgerigte betrokkenheid van die WRK en die SARK in die Suid-Afrikaanse kerklike lewe (Vorster, 1984 : 36-77). Die invloed van die Neo-Marxistiese Politieke Teologie word in Suid-Afrika ook verder uitgebrei deur die gewapende versetbewegings wat met morele steun en prinsipiële regverdiging van die WRK en SARK aan die versetstryd 'n skyn van christelikheid gegee het (De Braganca en Wallerstein, 1982:167-187). Vanweë hierdie toenemende aktualiteit is dit dus noodsaaklik om die inhoud van die stroming krities te beoordeel.

Om die inhoud en invloed van hierdie rigting te verstaan en te beoordeel is dit egier nodig om eers te let op die historiese lyne waarop die Neo-Marxistiese Politieke Teologie voortbou.

\section{Historiese lyne}

Oor die ontstaan van die Neo-Marxistiese Politieke Teologie maak Fierro (1977:77) die volgende stelling: "The recent appearance of political theology is due not so much to the traditional elements of Christianity as to the contemporary historical and cultural situation." Hoewel die uniekheid van die stroming sekerlik raakgesien moet word, is dit tog eensydig om die historiese wortels mis te kyk. 'n 
Ontleding van die werk van bogenoemde prominente teoloë wys daarop dat sekere figure en standpunte uit die verlede hulle stempel onteenseglik op dié moderne rigting afgedruk het. In die verband kan onderskei word tussen teologiese en filosofiese belnvloeding.

\subsection{Teologiese beinvloeding}

In die werke van die prominente Neo-Marxistiese politieke teoloë, word daar veral na drie teoloë van die verlede verwys. Hulle is Müntzer $(1490-1525)$; Bultmann $(1884-1976)$ en die skool van Bonhoeffer (1906-1945).

Müntzer as klassieke rewolusie teoloog is veral deur Bloch (1960) in herinnering geroep en hy is sodoende in die moderne teologie in moderne terminologie geromantiseer as 'n christelike aktivis wat hom beywer het vir die radikale verandering van die samelewing. Hy is dus nie soseer herontdek vir sy Anabaptistiese teologie nie, maar veel eerder vir wat hy gedoen het vanuit sy christelik-radikale oortuigings. Hy het homself gesien as apokaliptiese profeet wat op radikale wyse die Godsryk moet vestig (Müntzer, 1933:148). 'n Standpunt van Müntzer wat baie sterk deur Bloch $(1960: 219)$ en Fierro (1977:390) beklemtoon word, as dat dit vir 'n Christen onmoontlik is om te getuig in 'n verdrukkende totalitêre politieke sisteem. Juis hierosr beweer Fierro $(1977: 344)$ : "Indeed, that earlier figure casts his shadow over a broad segment of current theology."

Bultmann se bydrae lê in sy nuwe interpretasie en verklaringswyse van die Bybel. Met sy hermeneutiese beginsels van ontmitologisering het hy 'n Skrifbeskouing daargestel wat subjektiewe eksegese en gevolglik 'n byna onbeperkte panorama van teologiese moontlikhede moontlik gemaak het. Volgens hom moet die eksegeet deurdring tot dit wat agter die Bybelse "mite" sit. Sodoende kan 'n relevante Christendom, verlos van sy "onaanvaarbare" mitologiese denkbeelde daargestel word. Van sy "ontmitologisering" gee hyself 'n voorbeeld in sy verklaring van die Bybelse begrip: Koninkryk (Bultmann, $1976: 26$ ). Met hierdie metode het Bultmann 'n rewolusie in die Teologie veroorsaak. Hy het die deur oopgemaak vir allerlei subjektiwistiese teologiese eksperimente waarin gepoog word om 'n aktuele Christendom daar te stel waarin die moderne mens hom aangespreek vosl.

Veral Sölle (1972:8) het in die formulering van haar Politieke Teologie op sy uitgangspunt voortgebou. Volgens haar gaan dit by Bultmann om "geloof" en "verstaan". Sy denke word in die Politieke Teologie uitgebrei na "geloof" en "handeling". Bultmann se hermeneutiek moet dus gesien word as 'n uiters belangrike prinsipiële basis vir die opbou van die Neo-Marxistiese Politieke Teologie.

Die derde belangrike historiese lyn is Bonhoeffer en sy skool wat sedert 1945 baie invloed in die Teologie uitgeoefen het.

Bonhoeffer is nie soseer bekend om 'n uitgewerkte teologiese sisteem nie. Uit al sy geskrifte en briewe kom daar egter een sentrale tema na vore. Dit is dat die kerk en die gelowige vandag nie meer op supranaturalistiese wyse oor God kan spreek nie. Soos Bultmann sê hy dat die mondige mens nie meer 'n God aanvaar wat bo- 
natuurlik in die wêreldgeskiedenis ingryp en dit regeer nie. Bonhoeffer het hom daarom beywer vir 'n relevante Christendom wat iets te sê het vir die moderne wêreld. Hierdie relevante Christendom sentreer vir Bonhoeffer in die persoon van Jesus. Dáárom gaan dit vir hom ten diepste in die Teologie. God spreek net op een manier en dit is in sy selfopenbaring in die geskiedenis van Jesus (Bonhoef. fer, $1960: 104)$. Jesus was volledig mens-vir-andere. Hy het tot die lyde van ander toegetree en sy lewensdoel in sy naaste gevind. So was hy 'n ware voorbeeld van egte humaniteit en 'n navolgingswaardige persoon. Die kerk moet sy optrede bepaal deur Jesus se medelydende optrede en "kerk-vir-andere" te wees. Vir Bonhoeffer is dic hele spektrum van die christelike geloof dus medemenslikheid. Hierdie idee is veral deur Hamilton, Robinson, Van Buren, Tillich en Altizer uitgebou.

Müntzer, Bultmann en Bonhoeffer is die belangrikste historiese teologiese bydraers tot die teenswoordige Neo-Marxistiese Politieke Teologie. Müntzer se bydrae le in sy stryd as "Christelike aktivis" vir sosiale geregtigheid. Bultmann se bydrae lê in sy hermeneutiese metode van "ontmitologisering" wat 'n prinsipiële eksegetiese basis vir die Neo-Marxistiese Politieke Teologie daargestel het en Bonhoeffer se bydrae lê in sy verwerping van die konvensionele christendom en sy poging om 'n immanent gerigte sosiale heilsleer op grond van Jesus se prediking op te bou. Hierdie teologiese bydraes is verder aangevul deur enkele filosofiese lyne.

\subsection{Filosofiese beinvloeding}

Die naam Neo-Marxistiese Politieke Teologie sê dadelik watter filosofiese rigting hier ter sprake is. Dit is die Marxisme, soos dit deur Marx geformuleer is, maar ook in die afgelope drie dekades deur die Neo-Marxisme hersien. geslyp, uitgebou en toegepas is. Drie figure is hier van belang tewete Marx, Bloch en Marcuse.

Marx se bydrae le in sy sosiale analise, sy mensbeskouing en sy siening van politieke bevryding. Volgens sy sosiale analise is die Kapitalisme gebou op voortdurende klassestryd wat, benewens ag. gressie, lei tot uitbuiting en verarming van die werker. Die werker word 'n slaaf van die sisteem. "They mutilate the labourer into a fragment of a man, degrade him to the level of a appendage of a machine, destroy every remnant of charm in his work and turn it into a hated toil..." (Marx, 1967, vol 1:645). Die aggressiewe strydlustige mens is nie inherent sleg nie, hy word so as gevolg van die samelewing. Sy mensbeskouing is dus optimisties en hy glo dat die mens, met die regte uitwendige faktore soos 'n klaslose samelewing kan ontwikkel tot 'n volkome mens, d.w.s. 'n mens sonder selfvervreemding, eksploitasie en sisteemdwang. Die mens kan eers volkome mens wees as hy bevry word van die sisteem en dié bevryding moet radikaal en rewolusionêr wees. "To be radical is to grasp things by the root" (Marx, 1964:52). In die radikale bevryding is geweld geregverdif solank dit lui tot die totale omverwerping van die bestaande orde en die diktatuur van die proletariaat. Marx sien dit slegs as teengeweld. Hierdie beskouings van Marx het 'n wesent- 
like bydrae gelewer tot die sondeleer en verlossingsleer van die Neo-Marxistiese Politieke Teologie. Die bydrae is verder aangevul deur die filosofie van Bloch.

Bloch is 'n moderne Marxis en uitgesproke ateĩs. Tog het hy 'n duidelike en direkte invloed uitgeoefen op die moderne teologie. Die rede hiervoor beskryf Petulla (1972:13) soos volg: "It is not difficult to understand why Bloch has exercised such a profound influence on modern theologians, despite the disparity in both background and belief. His principal sourcebook is the Bible, which he secularizes radically." Veral twee gedagtes van Bloch moet nader aangedui word omdat dit 'n direkte invloed op die Neo-Marxistiese Politieke Teologie uitgeoefen het, tewete sy geskiedenisbeskouing en sy siening van die Eksodus-motief in die Bybel.

Sy beskouing van die geskiedenis rus op die stelling: "Wat is, kan nie waar wees nie" (Bloch, $1961: 65$ ). Waarheid is relatief. Dit is veranderlik en sien in verskillende tye verskillend daaruit. So is die geskiedenis 'n proses van verandering. En die waarheid lê juis in die proses van verandering. Daar moet dus altyd verandering en beweging wees. Die belangrikste produk van hierdie "historiese wet" is dat dit hoop gee. Die mens kan altyd hoop op verandering. Hierdie hoop is die fondament en rigtinggewende prinsipe in sy lewe en die inhoud van alle religie want: "Wo Hoffnung ist, ist Religion" (Bloch, $1970: 8$ ). Bloch se gedagte oor hoop is deur Moltmann (1967) tot 'n "Teologie van Hoop" uitgebou waarin hy sê dat hoopgewende verandering die uiteindelike taak van kerk en Teologie is.

As ondersteuning van sy geskiedenisbeskouing gebruik Bloch die sogenaamde Eksodus-motief in die Bybel. Hy sê dat die Bybel ook voortdurende verandering en beweging predik. God verander alles en die verandering bied hoop aan verdruktes. Benewens die Eksodusverhaal beroep hy hom op Skrifdele soos Jes $65: 17$ en Open 21:4 en sê hy dat die bedoeling van hierdie verse is om aan die noodlydende mens hoop te gee. Bloch se beskouing van die Eksodusmotief in die Bybel figureer sterk by Cox, Shaull, Moltmann, Banana en Cone en is, soos later aangedui sal word 'n belangrike tema in die Neo-Marxistiese Politieke Teologie.

Benewens die belangrike invloed van Marx en Bloch, moet die bydrae van Marcuse ook in berekening gebring word. Op grond van Marx en die psigo-analise van Freud het hy 'n sosiale analise en strategie van verandering uitgewerk wat diepgaande invloed op die sonde- en verlossingsleer van die Neo-Marxistiese Politieke Teologie uitgeoefen het. Freud het gesê dat onderdrukking van die mens se behoeftes lei tot aggressie. Marcuse pas dit op die samelewing toe. Wanneer mense deur strukture ingeperk word lei dit tot aggressie wat 'n vernietigingsdrif wakker maak. Volgens hom is dit die groot probleem in die Westerse wêreld. Die mens het 'n slaaf geword van politieke en sosiale strukture, in so 'n mate dat hy nie meer leef nie, maar geleef word (Marcuse, 1968:29). Om waarlik vry te wees moet die mens homself van die "gewelddadige" strukture bevry. En dit kan hy alleen doen deur die struktuur radikaal omver te gooi. Sy 
verset mag nie 'n passiewe verset wees nie, maar 'n algehele en alles-omvattende aktiewe anti-krag teen die bestaande. Dit sluit geweld in omdat alle ander demokratiese veranderingsmeganismes strukture nie omvergooi nie, maar slegs wysig. Hierdie beskouing van Marcuse is die direkte voedingsbron van Shaull se Teologie van Rewolusie en die WRK se Programme to Combat Racism (Vorster, $1981: 121)$.

Bogenoemde kort oorsig oor die teologiese bydraes van Müntzer, Bultmann en Bonhoeffer en die filosofiese bydraes van Marx, Bloch en Marcuse was nodig om die raamwerk te bied waarbinne die NeoMarxistiese Politieke Teologie geinterpreteer moet word. Met die standpunte in gedagte kan nou gelet word op die inhoud van die NeoMarxistiese Politieke Teologie.

\section{Die inhoud van die Neo-Marxistiese Politieke Teologie}

Die Neo-Marxistiese Politieke Teologie is nog nie 'n uitgewerkte teologiese sisteem nie. Die belangrikste aspekte van dié rigting waartoe verskeie teoloë meegewerk het kan tot vier hooftemas gereduseer word. Hierdie temas kan beskryf word as 'n nuwe hermeneutiek, 'n nuwe verlossingsleer, 'n nuwe ekklesiologie en 'n nuwe etiek.

\section{1 ' $n$ Nuwe Hermeneutiek}

Die hermeneutiek speel in hierdie rigting 'n besonder belangrike rol. Wat dadelik opval is die wye vertolking wat aan die hermeneutiek gegee word. Dit word nie soos tradisioneel in die Teologie, slegs gesien as die bestudering van beginsels van Skrifuitleg nie maar van die uitgangspunte, metode en doel van alle teologiese besinning. Alles word teruggevoer na een grondliggende stelling naamlik dat alle ' teologie kontekstueel moet wees. Dit beteken dat teologie verklaarbaar moet wees vanuit, en toepasbaar in die historiese situasie waarin die teoloog hom bevind.

Fierro (1977: 165) vat die kern van die saak saam met sy skerp stelling dat die eksegese nie die Teologie bepaal nie. Hy beweer dat die Bybel nog altyd deur die bril van die tyd gelees is. Die ontdekking van Bybelse beginsels vir ' $n$ bepaalde tydsgewrig is altyd bepaal deur die behoeftes van "present day faith". Teologie word dus nie deur die Bybel bepaal nie maar deur die behoeftes van die tyd en wêreld waarin die Bybel gelees word. Hierdie soort eksegcse wat 'n voortsetting is van Bultmann se ontmitologisering is veral deur Cox (1967:27) toegepas en bekendgestel. Toegepas op ons tyd sê Cox dat Teologie vandag nie anders as 'n teologie van sosiale verandering kan wees nie, omdat nood vandag politieke nood is en 'n nolitieke antwoord vereis. Dieselfde beskouing word gehuldig deur Sölle (1972:50). Cone (1973:52) en Boesak (1979:9).

Die nuwe Hermeneutiek bepaal dus dat die Skrif vanuit die lewenskonteks benader, geïnterpreteer, verklaar en as 'n kontekstuele bevrydingsboodskap toegepas moet word op die moderne samelewing met sy probleme. 'n Goeie voorbeeld van so 'n kontekstuele Skrifverklaring gee Kirk (1982:47) met sy weergawe van Kol 3:11: "Here there is no such thing as black man or white man, female or male, 
Mexican, American or North Viëtnamese - no, Christ is all, Christ is in all."

Die nuwe Hermeneutiek bring mee dat in hierdie Teologie weggedoen is met die bo-tydelike gerigtheid van die geloof. Alles wat heenwys na die nuwe bedeling, na die Wederkoms, is opnuut geinterpreteer en in kontekstuele verband verklaar. In hierdie verband moet veral gewys word op die nuwe interpretasie van die eskatalogie. In aansluiting by Metz, Moltmann en Schillebeeckz sê Fierro (1977:259) dat die eskatalogie in die Bybel nie die belofte van 'n nuwe hemel en aarde met die Wederkoms is nie. Wanneer die Koninkryk ontmitologiseer word, moet ons dit sien as 'n "bloudruk" van 'n ideale wêreld. God gee die ideaal-tipiese en die mens moet dit met sy politieke aksie daarstel. Gutierrez $(1979: 95)$ sê reguit: "To place oneself in the perspective of the Kingdom means to participate in the struggle for liberation of those oppressed by others."

Waartoe die Hermeneutiek inderdaad lei, word mooi saamgevat in Banana (1981:1) se weergawe van die Onse Vader:

"Our Father which art in the Ghetto,

Degraded is your name,

Thy servitude abounds

Thy will is mocked,

As a pie in the sky.

Teach us to demand.

Our share of gold,

Forgive us our docility,

As we demand our share of justice.

Lead us not into complicity,

Deliver us from our fears.

For ours is thy sovereignty,

The power and the liberation,

For ever and ever..., Amen."

\section{2 'n Nuwe Verlossingsleer}

Om 'n oorsig te gee van die nuwe verlossingsleer moet die volgende tema agtereenvolgens aan die orde gestel word: die leer oor die sonde, die leer oor Christus die leer oor bevryding, die leer oor versoening en die leer oor bekering.

In die dogmageskiedenis is deurgaans klem gelê op die sonde as ' $n$ inherente menslike eienskap. In beide die Rooms-Katolieke en Protestantse tradisies is, met nuanseverskille, gestel dat die mens ' $n$ inherente sondige aard het wat bestaan uit sondeskuld en sondesmet teenoor God. Hierteenoor word in die Neo-Marxistiese Politieke Teologie 'n radikaal nuwc siening van die sonde daarop nagehou, naamlik dat sonde nie setel in die hart van die mens nie, maar in die wêreld in die sogenaamde onderdrukkende sosio-politieke strukture. Veral Solle $(1972: 68)$ het, met 'n beroep op Marx, dit prinsipieel uitgewerk. Die sondige mens is volgens haar die mens wat, in terme van Marcuse, geleef word deur die samelewing sonder om daarteen in opstand te kom. Erfsonde is identifikasie met die wêreld waarin ons aankom, of te wel, kritieklose aanvaarding van ons sosio-politiese 
situasie. Dieselfde beskouing word, onder andere gevind by Tutu $(1983: 3)$ en hy probeer dit fundeer in die bronnehipotese ten opopsigte van Gen $1-3$.

Hiermee saam word 'n totaal nuwe beskouing oor Christus daargestel. Waar Christus in die konvensionele Christendom bely word as die Verlosser wat deur voldoening aan die geregtigheid van God die sondaar met God versoen, word Hy in die Neo-Marxistiese Politieke Teologie as die groot profeet van politieke bevryding gesien. Benewens Sölle, Lehman, Gutierrez en Cone fundeer Fierro (197: $161 \mathrm{ev)}$ die beskouing in die historiese situasie van Jesus. Hy sê dat die Dooie See rolle, wat lig werp op die maatskaplike milieu van Jesus aantoon dat daar 'n ononderbroke lyn is tussen Jesus, Johannes die Doper, die Esseners in die woestyn en "the Zealot guerillas also hiding out in the desert". Verder, sê hy, moet die skrifverklaarder aanvaar dat die teregstelling van Jesus 'n suiwer politieke teregstelling was. Christus was dus 'n politieke bevryder. Buti (1979:13) sê dan ook ten opsigte van die swart stryd in Suid-Afrika: "Christ is the liberator, He identifies Himself with your struggle, and therefore I do it too in obedience with Him. He calls me as a Christian to stand in solidarity with you to suffer as you suffer, to risk rejection, ostracism, yes even imprisonment, until all of us are free."

In lyn met die sondeleer en leer oor Jesus, word die Neo-Marxistiese model van bevryding dan oorgeneem as die kern van die christelike verlossingsleer. Met bevryding word soos Marcuse dit uitspel, bedoel die ontsetting van die mens uit die verknegting van sodanige strukture. Hiervoor het baie teoloë uit hierdie kringe 'n Skrifberoep probeer vind (Vorster, 1984:95ev), waarvan die belangrikste die Eksodus-motief is. Cox en Guttierez sê op voetspoor van Bloch dat die sogenaamde Eksodus-motief in die Bybel toon dat God ten gunste van beweeglikheid en verandering is en dat deurlopende sosiale verandering die kernboodskap van die Bybel is. Tutu (1980:16) sê dat God Hom hiermee bewys as 'n "God of Liberation, the great Exodus God, who took the side of the oppressed, the exploited ones."

Met die beskrywing van God as die "Eksodusgod", Christus as Bevryder en bevryåing as die dieptepunt van die Bybelse boodskap, is die stroming daarvan vol dat die Christelike geloof 'n "godsdiens vir verdruktes" is. Volgens die siening het geloof dan slegs betekenis vir mense wat deur politieke strukture verkneg en verdruk word (Fierro, $1977: 12$ ). God en Jesus is aan die kant van die verdruktes. Hierdie beskouinge het ontwikkel tot gewilde teologiese slagspreuke. In hierdie verband kan gewys word op die bydraes van Banana (1981) en Tutu (1981).

Banana (1981:23) sê in 'n gedig:

"God's solidarity with the oppressed,

And His judgement of the oppressor

Assures us that,

Beyond the darkening skies,

Of our present struggles,

There lies a brighter tomorrow." 
'Ten opsigte van versoening en bekering word in die Teologie die volgende gesê: Versoening is nie versoening tussen God en gelowige nie, maar versoening tussen mense. Volgens Shaull (1969:50) beteken "koinonia" wêreldgemeenskap en solidariteit. In die opbou van die wêreldgemeenskap moet die kerk die voorloper wees. Hierdie koinonia is die "alternative society" wat oral, ook in die RSA, verwerklik moet word. Bekering is 'n daad van toetree tot die naaste. Gutierrez (1974:96) sê: "A spirituality of liberation will centre on a conversion to the neighbour, the oppressed person, the exploited social class, the despised race, the dominated country". Bekering van die individu kan net gemeet word in die mate waarin hy hom beywer vir sosiale geregtigheid.

\section{3 'n Nuwe Ekklesiologie}

Twee uitsprake van prominente Suid-Afrikaanse teoloë gee 'n baie treffende beskrywing van die visie van die Neo-Marxistiese Politieke Teologie op die wese en taak van die kerk. Teenoor die tradisionele belydenis van die kerk "as gemeenskap van die gelowiges" sê Ntwasa (1973: 114ev): "The Church therefore cannot be seen simply as the company of believers who have had spiritual experiences. It is the company of those whose lives are perceived to have the quality of Christ-in-his-strugg!e-against human bondage. It is a company of liberators, or it is not the Church." Hy sien die kerk dus as 'n gemeenskap van bevrydiers wat sosio-polities gerig is. Ten opsigte van die taak van die kerk sê Boesak $(1979: 25)$ : "The black church like Moses, is not called to negotiate with the Pharaoh - it is called simply to convey the Lord's command: Let my people go". Die kerk is in sy takkvervulling die "derde" Moses wat soos Moses in Egipte en Jesus in die Romeins oorheersde Judea die mens moet bevry.

Die leer oor die kerk in die Neo-Marxistiese Teologie kan só saamgevat word: Die kerk is ' $n$ korporatiewe eenheid van almal met 'n sosiale gewete wat tot hulle naaste "bekeer" is, wat aksie het teen sogenaamde verdrukkende politieke strukture, wat gebonde is aan die ideaal van die daarstelling van 'n wêreldgemeenskap en solidêr is met armes en verdruktes en alle groepe wat dieselfde doel voor oё het. Kerngedagtes van die Neo-Marxisme, soos vroeër uiteengesit word hierin duidelik weerspieël en die ekklesiologie gee 'n duidelike verklaring van die oorwegende politieke aksies van die SARK en WRK en verskeie kerkgroepe in Suid-Afrika.

\section{4 'n Nuwe Etiek}

Die inhoudelike uiteensetting tot dusver het twee baie belangrike eienskappe van die Neo-Marxistiese Politieke Teologie herhaaldelik aangetoon. Aan die een kant is die Teologie daarvan vol dat die huidige wêreld onaanvaarbaar is vanweë sy strukturele sondes. Aan die ander kant word die ideaal van 'n beter wêreld, of utopie, geesdriftig as die doel van menslike aksie voorgehou. Tussen hierdie twee pole word die nuwe etiek uitgewerk. Dit kan beskryf word as 'n kontekstuele etiek wat sy regverdiging vind in die ideaal van 'n beter wêreld en sy motivering in die bestryding van die status quo. 
Die liefde wat tradisioneel die grondslag is van die Christelike Etiek, ontvang in dié nuwe etiek 'n ander beklemtoning. Dit word gesien as die doel van alle menslike handeling. Hierdie doel kan alleen bereik word wanneer alle onreg onvrede, verdrukking en eksploitasie uit die weg geruim word (Fierro, $1977: 255$ ). Om die liefde te konkretiseer moet die christen self die middel uitwerk. Die Bybel gee die ideaal - die mens moet die middel self vind.

Die middel word dan gevind in die etiek van bevryding soos deur Marcuse uitgewerk. Die mens moet homself bevry van die eendimensionele samelewing waarin hy teen sy sin gemanipuleer word en in sy behoefte-uitlewing beperk word. Omdat die samelewing met al sy beperkende wette in wese gewelddadig is en so deur polisie in stand gehou word, mag geweld daarteen ingespan word. Sulke "teen-geweld" is geregverdig. Die nuwe etiek sentreer dan om geweld as metode. Dit is geregverdig omdat dit geweld is wat "bevry" teenoor die geweld wat "verdruk" (GKN, 1973 en 1975b:72). Dit is veral Camara (1974:139) wat hierdie tema in besonderhede uitgewerk het en die etiek van die Marxisme "verchristelik" het. Die kern van die etiek is stryd teen strukture. En wanneer daardie stryd geweld impliseer, is dit aanvaarbaar, want dit is "geweld wat bevry". En bevryding is per slot van sake die uiteindelike bedoeling van God met die mens en die rigting van die geskiedenis.

\subsection{Samevatting}

Die Neo-Marxistiese Politieke Teologie is 'n sinkretisme tussen die basiese motiewe van Marx en die Neo-Marxisme aan die een kant en kerntemas van die Christelike geloof aan die ander kant. Dit is waarlik 'n poging om Marx en Jesus te versoen. Die volgende stellings is ' $n$ duidelike aanduiding van die vrugte van dié versoeningspoging:

3.5.1 Marx en Marcuse ontbloot met hulle onderskeie sosiale analises die moderne: wêreld as 'n wêreld van sosiale onreg. Die onreg is geleë in verdrukkende en beperkende sosio-politiese strukture. Die Neo-Marxistiese Politieke Teologie aanvaar presies dieselfde uitgangspunt, maar kamoefleer dit in die Bybelse woord "sonde". Die konklusie is dan: sonde is sosiale onreg en setol in strukture.

3 5.2 Die Marxisme en Neo-Marxisme strewe na 'n aardse heilstaat en dít beteken 'n nuwe wêreld met 'n nuwe wêreldgemeenskap sonder sosiale onreg. Die Neo-Marxistiese Politieke Teologie aanvaar presies dieselfde doelstelling. Die "aardse heilstaat" word net genoem: Koninkryk van God.

5.3.3 Die Marxisme en Neo-Marxisme kies rewolusie as middel tot 'n beter wêreld. Die rewolusie moet op strukturele bevryding gerig wees, mel teengeweld as middel. Dieselfde motiewe word net so oorgeneem in die Neo-Marxistiese Politieke Teologie onder die "Bybelse" terme: verlossing, bekering en versoening.

3.5.4 Die Marxisme en Neo-Marxisme sien onderskeidelik die werkers en die studente as voertuig van die rewolusie. Die Neo-Marxistiesc Politieke Teologie ken dieselfde taak toe aan 
die kerk, wat vryheid op dieselfde wyse moet soek as die grootste "vryheidsvegter" van alle tye: Jesus van Nasaret met sy "Nazareth Manifesto" (Hirmer, $1981: 88$ ).

\section{Beoorcieling}

Baie kan gesê word in die beoordeling van die Neo-Marxistiese Politieke Teologie. (Vgl Vorster, 1984:117). Binne die bestek van hierdie artikel word kortliks op die volgende gewys.

\subsection{Die bydrae van die Neo-Marxistiese Politieke Teologie}

Dit moet erken word dat die stroming gekenmerk word deur maatskaplike bewoënheid. 'n Diepgaande belangstelling word getoon in die nood van mense - 'n nood waarvoor kerke vir baie lank die oë gesluit het. Op sigself moet die uitwys van maatskaplike nood beskou word as ' $n$ belangrike bydrae. Die onbewoënheid wat kerke in die verlede getoon het, word treffend deur Banana (1981:19 en 20) in die volgende gedig uitgedruk:

When I was lonely,

You left me alone.

When I was homeless,

You preached to me about the shelter of God's love.

When I was hungry,

You formed a humanity's club and discussed my hunger,

When I was naked,

You debated about the morality of my nakedness.

When I was in prison,

You guiltily crept into a cellar and prayed for my release.

When I was sick,

You fell on your knees and thanked God for your health.

You seem to be so Holy,

so close to God,

But I am still hungry. lonely and cold".

Hiermee saam toon die rigting 'n politieke bewustheid en word veral gewys op die belangrikheid van politieke beleid in die lewe van mense. Dit is so dat alle fasette van die moderne lewe gepolitiseer is dit wil sê dat die lewe gereguleer word deur wette wat bepaal word deur politieke beleid en ekonomiese noodsaak. Aangesien dic Evangelie ook die hele lewe raak is dit vanselfsprekend dat die bediening van die Woord, die roeping van die kerk en die beoefening van die Teologie nie die politiek kan systap nie. Die implikasies vir dic politiek moet duidelik uitgespel word en die uitwys van hierdie waarheid is ' $n$ verdere bydrae van die Neo-Marxistiese Politieke Teologie.

Juis vanweë sy maatskaplike bewoëndheid en politieke bewustheid, staan die Neo-Marxistiese Politieke Teologie fel afwysend teenoor 'n piëtistiese godsdiensbeskouing. Onder "piëtisme" word ver. staan die strewe om die Christelike geloof te laat opgaan in persoonlike mistieke ervaringe met 'n gepaardgaande gees van kultuurontvlugting en wêreldmyding. Die klag van die moderne Teologie teen die tradisionele Christendom is dat die piëtisme daartoe gelei het dat politiek vermy is en te min gedoen is om onreg te bestry. Die piëtis- 
me het die kerk langs die wêreld geplaas en nie in die wêreld om ook besig te bly met die probleme van die wêreld nie. Myns insiens is hierdie klag grotendeels geregverdig.

\subsection{Kritiek op die Neo-Marxistiese Politieke Teologie}

'n Apologetiese beoordeling kan nie anders nie as om uit te gaan van die vraag: Hoe word die Skrif gebruik? In hierdie verband kan gesĉ word dat die Teologie nie 'n uitgewerkte Skrifbeskouing bied nie. Die Bybel word eenvoudig gebruik as 'n historiese gegewenheid wat in sy historiese konteks verklaar en eksemplaries toegepas moet word. Daarby is die hermeneutiese uitgangspunt die eise van die moderne samelewing. Vanuit die sisteem word na die Bybel beweeg en dit is vanselfsprekend dat die Bybel op hierdie wyse op enige subjektiewe manier gebruik kan word. Wat vandag waar is, is môre nie noodwendig waar nie. Die Gereformeerde Skrifbeskouing en die nuwe hermeneutiek staan dus reglynig teenoor mekaar en dit het nie sin om die eksegese van hierdie teoloë te beoordeel alvorens dic saak van Skrifbeskouing nie uitgemaak is nie.

Die belangrike verskilpunte in hierdie verband lê dus daarin dat die moderne politiek gebruik word as hermeneutiese uitgangspunt in Skrifverklaring en dat op die basis gewerk word van historiese en nie openbaringshistoriese eksegese nie. Fierro (1977:353) tipeer die beskouing treffend met 'n uitspraak van Assmann: "The Bible? The Bible does not exist. The only Bible that exists is the sociological Bible of what appears here as Christian! The Bible? I know of only one Bible; the sociological Bible of facts and events here. Everything else is an abstraction."

Die Skrifgebruik van die Neo-Marxistiese Politieke Teologie is sekulêr, en dit is die grootste en deurslaggewende punt van kritiek wat téén dié rigting ingebring kan word. Op grond van hierdie kardinale punt van kritiek kan ook die volgende kritiese opmerkings gemaak word:

Eerstens moet gesê word dat die subjektiwisme in Skrifverklaring die rigting oopmaak vir ideologiese beïnvloeding. As van die situasie na die Bybel beweeg word moet die situasie eers gedefinieer word. Dit is duidellk dat so ' $n$ definisie vanuit 'n bepaalde hoek gedoen word. In hierdie geval is dit die hoek van die Marxisme. Deur die bril van Marx en die Neo-Marxisme word die samelewing gediagnoseer en dan word by wyse van sosiologiese en historiese eksegese gaan soek na sogenaamde Bybelse antwoorde. En omdat die vraag die antwoord bepaal word die Bybel aangewend as regverdiging van antwoorde wat ten diepste uit die stal van Marx en die Neo-Marxisme kom.

So word die koninkryk van God verklaar as 'n aardse utopie wat deur menslike handeling, en in besonder, rewolusie daargestel moet word. Christus en Marx word versoen. Jesus gee die model van 'n beter wêreld en Marx gee die metode om die model te verwesentlik. Die ideologiese beinvloeding lei uiteindelik ook na 'n humanistiese verlossingsleer waarin sonde buite die mens gestel word, verlossing 
vereng word tot politieke bevryding en Jesus verlaag word tot 'n tydelike historiese politieke bevryder. Die versoening word eweneens gedegradeer tot ' $n$ historiese strewe na wêreldgemeenskap en solidariteit met verdruktes en bekering word slegs die betrokkenheid van die individu by politieke verandering. Hierdie beskouing is niks anders nie as 'n restourering van Marx in christelike terminologie.

Die sekulêre Skrifbeskouing en ideologiese beĩnvloeding van die Neo-Marxistiese Politieke Teologie lei ook tot 'n deformasie van die kerk. Die kerk word voorgehou as 'n instituut van "bevryders" wat op voetspoor van die historiese Jesus en Moses hom moet beywer vir strukturele bevryding. Hiervoor is die beroep op Marx sterker as Bybelse fundering. By Marx is die bevryders die arbeiders, by Marcuse is dit die studente, by die Neo-Marxistiese Politieke Teologie is dit die kerk. Die deelname van die SARK en die WRK by Marxisties geïnspireerde bevrydingsbewegings, onder andere in SuidAfrika, is hiervan die duidelike bewys.

Tweedens is dit opmerklik dat in dié rigting die christelike lewe geheel en al gepolitiseer word. Die moderne lewe is wel polities bepaal en kan nie van die verkondiging van die Evangelie en die roepingsvervulling van die kerk losgemaak word nie. In hierdie opsig is die Neo-Marxistiese Politieke Teologie wel korrek. Tog is dit onverantwoord om uit die realiteit die afleiding te maak dat die christelike lewe gehee! en al wêreld en polities gerig moet wees. Die christelike lewe is veel meer as dit. Dit is die stryd om heiligmaking wat in terme van die Dortse Leerreëls (hfst 5) inhou dat die heiliges vanweë die smet van die sonde gedurig rede het “... om hulle voor God te verootmoedig, hulle toevlug tot die gekruisigde Christus te neem, die vlees hoe langer hoe meer deur die Gees van die gebed en deur heilige oefening van godsvrug te kruisig en na die eindpaal van volmaaktheid so lank te smag totdat hulle, ontbonde van hierdie lig. gaam van die sonde, in die hemele met die Lam van God sal regeer." Omdat in dié moderne rigting die sonde buite die mens gesoek word kom van die heiligmaking niks tereg nie en word dic essensic van christen-wees tersyde gestel.

\section{Slotopmerkings}

Dit sou dwaas wees om die bydrae wat die Neo-Marxistiese Politieke Teologie maak, mis te kyk. Want per slot van sake word hier 'n onbetaalde rekening van die konvensionele christendom aangedui. Maar dit sou ewe dwaas wees om die ingrypende en diepliggende dwaling in die rigting te ignoreer. Hierdie Teologie is die "teologie" van die WRK, die SARK, die kerke in die Derde Wêreld en op die huidige stadium die geestelike voeding van miljoene, hoofsaaklik swart, gelowiges in Suid-Afrika. Ook gereformeerde lidmate staan in die spervuur.

Wat kan ons hierop antwoord? Myns insiens lê die antwoord nié in ' $n$ alternatiewe Politieke Teologie wat op 'n ander wyse met sosiopolitieke nood wil omgaan nie. So 'n antwoord gaan mank aan dieselfde basies gebreke as die Neo-Marxistiese Politieke Teologie. Die antwoord is maar net die eeue-oue opdrag aan die gelowige: Verkon- 
dig die Evangelie; roep op tot geloof en bekering en beoefen die liefde in alle lewensfasette - ook veral in die politiek waar die lewens van miljoene bepaal word.

\section{BIBLIOGRAFIE}

Boesak, A. 1977. Afscheid van de onschuld, een sociaal ethische studie over zwarte theologie en zwartc macht. Kampen, J. H. Kok.

Boesak, A. 1979a. The Black Church and the future. Ecunews, 24/1979 p. 19ev

(Ook opgeneem in The Ecumenical Review 1980 Vol, 32 p. 16-32 onder die titel: The Black Church and the struggle in South Africa).

Bloch, E. 1960. Thomes Muntzer als Theologe der Revolution. Frankfurt, Susterkamp.

Bloch, E. 1961. Philosophische Grundfragen I. zur ontologie des Noch - Nicht - Seins. Frankfurter am Maim.

Bloch, E. 1970b. Religion im Erbe. Eine Auswahl aus seinen religion-philosophischen Schriften. Munchen und Hamburg. Siebenstern Taschenbuch Vertag.

Bonhoeffer, D. 1960b. Vom Dankbarkeit des Christen. (In sy Gesammelte Schriften, Munchen. Chr. Kaiser Vertag, Vol. III).

Bultmann, R. 1967. Jesus Christus en de mythe. Amsterdam, W. ten Have.

Buti, S. 1979. The shadows of death and the future of hope of South Africa. Ecunews. 24/1979 p Oev.

Camara, H. 1974. Violence - the Only Way. (In Kee, A. red. A reader in Political Theology, London. SCM Press. p. 139ev).

Cone, J. H. 1973. Black Theology and black liberation. (In Moore, B. red. The challenge of Black Theology in South Africa. VSA. Atlanta, John Knox Press. p. 36-47).

De Braganca, A. \& Wallerstein, I. 1982. Editors note (In hulle The African Liberation Reader, documents of the national Liberation Movements. London, Zed Press. Vol. 2 p. 180ev).

Fierro, A. 1977. The Miliant Gospel. An analysis of Contemporary Political Theologies. London. S.C.M. Press. (Oorspronklike titel: El evangelio beligerante).

Gereformeerde Kerken in Nederland. 1973 en 1075b. Programma ter bestrijding van het rascisme. rapport aan die Generale Synode van Haarlem 1973-1975, van de GKN. Opgestel deur die Generale deputaten voor de Algemene Diakonale Arbeid: Generale deputaten voor de Zending en die Generale deputaten Oecumene (Buiteland). Leusden. Alg. diensburo van die GKN. Verwnr. 136.

Gutierrez, G. 1974a. Thenlogie van de bevrijding. Baarn Ten Have. Hirmer, O. 1981. Marx Money Christ Zimbabwe. Gweru. Mambo Press.

Kirk, D. 1982 Quołations from Comrade Jesus. Gwure Mambo Press.

Marcuse. H. 1986. Eros en cultuur. Utrecht. Uitgeverij Erven J. Bijleveld.

Marcuse, H. 1971a. De eendimensionele mens; studies over de ideologie van de hoog-industriele samenleving. Busjum. Paul Brand. 
Marx, K. 1964. Early writings. New York, McCraw Hill.

Marx, K. 1976. Capital. Engeland. Middlesex, Harmondsworth. Penguin Books Ltd. 3 Volumes.

Moltmann, J. 1967. Theology of hope. London. S.C.M. Press.

Muntzer, T. 1933. Thomas Muntzer. Sein Ieben und sein Schriften. Jena. Eugen Diedericks Verlag.

Ntwasa. S. 1973. The concept of the Church in Black Theology. (In Moore, B. red. The challenge of Black Theology in South Africa. VSA, Atlanta, John Knox Press. p. 109-118).

Petulla, J. M. 1872. Christian Political Theology. a Marxian guide. New York, Maryknoll.

Shaull, R. 1969a. Uitdaging aan kerk en maatschappij. Baarn, Het wereldvenster.

Sölle, D. 1970. Fantasic en gehoorsaamheid, toekomst en christelijke etiek. Baarn. Bosch en Keuning.

S6lle, D. 1972. Politieke theologie, discussie met Rudolf Bultmann. Baarn. Bosch en Keuning.

Tutu, D. 1980a. The challenge of the 80's. Ecunews. $10 / 1980$ p. 11.

Tutu, D. 1981. The role of the Church in South Africa. Ecunews, 3/1981 p. $11 \mathrm{ev}$.

Tutu. D. 1983a. The way of obedience. Ecunews 4/1983 p. 3 .

Vorster, J. M. 1981a. Die kerk en die kleurvraagstuk vandag. Johannesburg, De Jongh Uitgewers.

Vorster, J. M. 1984. Die Neo-Marxistiese Politieke Theologie in Suid-Afrika. Ongepubliseerde Th.D proefskrif, Potchefstroom, P.U. vir C.H.O. 